\title{
Variable indicators affecting the country's brand strategy effectiveness and competitiveness in the world
}

\author{
Tetiana M. Melnyk ${ }^{\mathrm{a}}$ and Anna S. Varibrusova $\mathrm{a}^{*}$
}

${ }^{a}$ Kyiv National University of Trade and Economics, Kyiv, Ukraine

\begin{tabular}{l}
\hline C H R O N I C L E \\
\hline Article history: \\
Received: April 18, 2019 \\
Received in revised format: April \\
282019 \\
Accepted: May 18, 2019 \\
Available online: \\
May 18, 2019 \\
\hline Keywords: \\
Country brand \\
National branding \\
Country's global competitiveness \\
National branding strategies
\end{tabular}

\section{Introduction}

In the context of growing global competition, national branding is an effective tool for strengthening the image of the country, its investment and tourism attractiveness, and, consequently, raising the level of international competitiveness of the state. Using such a tool as branding provides a huge advantage. Manufacturers of branded goods, thus distinguishing themselves among competitors, receive more profit. National branding operates at the state level in the same way. Its use creates additional competitive advantages in the national and international spheres of the country's activity. At present, although this tool is not quite common, an increasing number of countries are resorting to national branding. The current trend is a marked improvement in the positions of developing countries in the rankings of country brands. Their success is due to increased attractiveness in specific areas, but the evaluation according to other

* Corresponding author

E-mail address: varibrusova@ukr.net (A. S. Varibrusova)

C 2019 by the authors; licensee Growing Science, Canada doi: $10.5267 /$ j.msl.2019.5.019 
criteria remains significantly lower than in developed countries. This requires identifying key factors that contribute to strengthening the international image of countries in the world economy, improving the methods for evaluating the Country Brand Index, substantiating the strategies of developing the country brand in the global competitive environment.

The studies of both scholars and practitioners in the areas of international economics, business and marketing deal with the problems of the introduction and development of the country brand. The issues of the methodology of national branding are considered in the works of Anholt (2007), Aronczyk (2013), Fan (2006); evaluation and analysis of country brands are investigated by Dinnie (2008), Papadopoulos and Heslop (2002), Fetscherin (2010); problems of strategic brand management are covered by Kotler and Gertner (2002), Temporal (2014), Keller (2012). The works of domestic researchers deal with various issues of the international image of Ukraine (Polishko, 2013; Shtelmashenko, 2013), problems of territorial branding (Nahorniak, 2010), marketing aspects of the country brand promotion (Shevchenko, 2003; Starostina et al., 2011; Zavhorodnia 2010), and others. However, the complexity of such phenomenon as a country brand requires active methodological work on the image ranking system, especially in terms of identifying and adequately reflecting the characteristics of the state which are attractive to the world community. In this regard, the tools for evaluating the Country Brand Index, taking into account the level of the country's competitiveness require further improvement, and on this basis formulating strategies for the development of national branding in the context of global competition.

The objective of the research paper is to evaluate the integral Country Brand Index, based on the determination of key factors influencing its formation in the context of global competition, as well as formulation on this basis of strategies for the development of the potential of a country brand and the competitiveness of the state.

\section{Methods and Materials}

The theoretical and methodological background for this research paper is the reports of leading global organizations in the field of national branding and competitiveness - Brand Finance, Anholt-GfK, Bloom Consulting, FutureBrand, PWC, World Economic Forum, and the works of domestic and foreign scholars on this issue. The research was conducted using the methods of theoretical generalization, comparative analysis, analysis and synthesis, which allowed determining the positions of the countries in the leading branding rankings, generalizing the factors that directly influence the formation of the country brand; methods of economico-mathematical modelling and factor analysis for determining the main components of the integral Brand Index; Shell/DPM Strategic Analysis and Planning Model for developing the promising strategies of country brand and global competitiveness.

The research paper uses statistical data of the OECD, the IMF, the World Bank, UNCTAD, Eurostat and the State Statistics Service of Ukraine for the period from 2000 to 2017.

\section{Results and Discussion}

As a result of the analysis of the theoretical and methodological principles of the formation of a country brand (CB) and a comparative analysis of the implementation of national branding in order to ensure global competitiveness of the countries, the main variables of indicators that influence the effectiveness of the brand strategy are systematized:

$\mathrm{X}_{1}$ - real GDP change, \%;

$\mathrm{X}_{2}$ - inflow of direct foreign investments, annual change, $\%$;

$\mathrm{X}_{3}$ - growth of exports of goods and services (annual change, \%);

$\mathrm{X}_{4}$ - gross fixed capital formation (GFCF, $\%$ of GDP);

$\mathrm{X}_{5}$ - employment level, \%;

$\mathrm{X}_{6}$ - index of real wages, \%; 
$\mathrm{X}_{7}$ - share of population's income in GDP, \%;

$\mathrm{X}_{8}$ - labor productivity;

$\mathrm{X}_{9}$ - index of government employment protection;

$\mathrm{X}_{10}$ - cost of social protection of population, $\%$ of GDP;

$\mathrm{X}_{11}$ - foreign activity of TNCs, annual change, $\%$;

$X_{12}$ - financial result of TNCs in the country of location (annual change, \%);

$\mathrm{X}_{13}$ - gross domestic R\&D expenditure - GERD (share of GDP), \%;

$\mathrm{X}_{14}$ - population access to ICT, \% of households;

$\mathrm{X}_{15}$ - innovations expenditures of corporations - BERD (share of GDP), \%;

$\mathrm{X}_{16}$ - share of innovative enterprises, $\%$

20 countries with different levels of development and data of the above indicators from OECD (n./d.) statistics have been taken for the study.

To select the number of significant factors, the criterion of Kaiser (1960) was used. According to this criterion, the factor is not included in the number of significant ones if it does not explain the dispersion of at least one initial characteristics. Therefore, the number of factors is considered equal to the number of the values of the correlation matrix of features, which are greater than 1 .

The number of selected economic indicators and their appropriateness for the formation of the integral indicator of the country brand in the context of global competitiveness can be established by using the principal components analysis (Afifi \& Azen, 1982). This method is to replace the correlated characteristics with non-correlated factors. When applying the principal components analysis, the total variance of the obtained factors is equal to the total variance of the initial characteristics. Another important feature of the method is the ability to reduce to the most informative key components and exclude others from the analysis, thus simplifying the interpretation of the results. The unifying indicators selected on the basis of the principal components analysis are identified, some of which have the properties of several variables at once, allow, as a result of their interpretation, explaining the most influential factors that form these indicators. As a result of multivariate statistical analysis, 16 input indicators were divided into 4 groups of integral factors (Varimax component rotation method was used), whose economic interpretation shows their qualitative and quantitative contribution to the corresponding component (macroeconomics, social policy, corporate component and innovation policy) in the formation of the Country Brand Index. The results of the selection of the main components are presented in Table 1.

\section{Table 1}

Results of factor analysis using the principal components analysis (developed by the author based on $\operatorname{OESD}$ (n./d.))

\begin{tabular}{|c|c|c|c|c|}
\hline Indicators & Factor 1 & Factor 2 & Factor 3 & Factor 4 \\
\hline Real GDP, $\%$ & 0.939985 & 0.202713 & 0.179502 & -0.021896 \\
\hline FDI inflow (annual change, \%) & 0.982223 & 0.058415 & 0.146201 & 0.103194 \\
\hline Growth of exports of goods and services (annual change, \%) & 0.909634 & 0.192415 & 0.200832 & -0.024335 \\
\hline Gross fixed capital formation (GFCF, $\%$ of GDP) & 0.115106 & 0.694057 & 0.158405 & -0.122662 \\
\hline Employment level, \% & -0.049533 & 0.872115 & 0.160682 & 0.082872 \\
\hline Index of real wages, $\%$ & 0.187346 & 0.768516 & 0.243714 & -0.055168 \\
\hline Share of population's income in GDP, \% & 0.306295 & 0.403916 & 0.353205 & -0.254485 \\
\hline Labor productivity & -0.002666 & 0.851036 & 0.078594 & -0.109872 \\
\hline Index of government employment protection & -0.322927 & 0.547043 & -0.124183 & 0.425797 \\
\hline Cost of social protection of population, $\%$ of GDP & -0.229619 & 0.035185 & -0.561306 & 0.044752 \\
\hline Foreign activity of TNCs, annual change, $\%$ & 0.204595 & -0.417748 & 0.968909 & 0.069834 \\
\hline Financial result of TNCs in the country of location (annual change, \%) & 0.497001 & 0.032966 & 0.217483 & 0.576783 \\
\hline Gross domestic R\&D expenditure - GERD (share of GDP), \% & -0.046964 & -0.167817 & -0.238537 & 0.949491 \\
\hline Population access to ICT, $\%$ of households & 0.079728 & -0.127654 & -0.660246 & -0.567121 \\
\hline Innovations expenditures of corporations - BERD (share of GDP), $\%$ & -0.046964 & -0.167817 & -0.238537 & 0.649491 \\
\hline Share of innovative enterprises, $\%$ & 0.173763 & -0.25467 & 0.067411 & 0.951084 \\
\hline Total variance & 2.831 & 2.491 & 0.968 & 1.901 \\
\hline Share of total variance & 0.315 & 0.277 & 0.108 & 0.212 \\
\hline
\end{tabular}


The first integral factor of the country brand model is interpreted as a macroeconomic one (the share of contribution of the factor to the integral Country Brand Index is 31.5\%), the second factor - the social component forms the resulting indicator by $27.7 \%$ ), the contribution of the third factor determined as corporate, is $10.8 \%$, the fourth factor represents the innovative component of the Country Brand Index and forms it by $21.2 \%$. As a result, according to the given model, the total contribution of the selected factors to the formation of the Country Brand Index is $91 \%$. Thus, application of the principal components analysis enabled to identify the nine most influential variables that form the indicator of the country brand (Table 2).

Table 2

Factors affecting the national brand

\begin{tabular}{|c|c|c|c|c|c|c|c|}
\hline \multicolumn{2}{|c|}{$\begin{array}{c}\text { Macroeconomic component } \\
\text { Factor } 1 \\
\end{array}$} & \multicolumn{2}{|c|}{$\begin{array}{c}\text { Social component } \\
\text { Factor } 2 \\
\end{array}$} & \multicolumn{2}{|c|}{$\begin{array}{c}\text { Corporate component } \\
\text { Factor } 3 \\
\end{array}$} & \multicolumn{2}{|c|}{$\begin{array}{c}\text { Innovation component } \\
\text { Factor } 4 \\
\end{array}$} \\
\hline Factor & Indicator & Factor & Indicator & Factor & Indicator & Factor & Indicator \\
\hline $\begin{array}{l}\text { 1. Economic } \\
\text { growth }\end{array}$ & $\begin{array}{l}\text { GDP (real } \\
\text { growth), } \%\end{array}$ & $\begin{array}{l}\text { 4. Human } \\
\text { capital }\end{array}$ & $\begin{array}{l}\text { Employment } \\
\text { level, } \%\end{array}$ & $\begin{array}{l}\text { 7. Economic } \\
\text { activity of } \\
\text { TNCs }\end{array}$ & $\begin{array}{l}\text { Foreign activ- } \\
\text { ity of the } \\
\text { TNCs }\end{array}$ & $\begin{array}{l}\text { 8. Innovation } \\
\text { development }\end{array}$ & $\begin{array}{c}\text { Gross domestic } \\
\text { R\&D expenditure } \\
\text { - GERD (share of } \\
\text { GDP), } \%\end{array}$ \\
\hline 2. Investment & $\begin{array}{l}\text { FDI inflow } \\
\text { (annual } \\
\text { change, \%) }\end{array}$ & $\begin{array}{l}\text { 5. Living } \\
\text { standards of } \\
\text { the popula- } \\
\text { tion }\end{array}$ & $\begin{array}{l}\text { Change in real } \\
\text { wages, } \%\end{array}$ & & & $\begin{array}{l}\text { 9. Innovation of } \\
\text { business }\end{array}$ & $\begin{array}{l}\text { Share of innova- } \\
\text { tive enterprises, } \%\end{array}$ \\
\hline 3. Foreign trade & $\begin{array}{l}\text { Growth of ex- } \\
\text { port of goods } \\
\text { and services } \\
\text { (annual } \\
\text { change, } \%)\end{array}$ & $\begin{array}{l}\text { 6. Employ- } \\
\text { ment effec- } \\
\text { tiveness }\end{array}$ & $\begin{array}{l}\text { Labor productiv- } \\
\text { ity index, GDP to } \\
\text { employed ratio }\end{array}$ & & & & \\
\hline
\end{tabular}

As Table 2 shows, in the component "Macroeconomics", the following indicators have the greatest load on the resultant factor:

- Economic growth - GDP (real growth);

- Investment activity - annual change of FDI inflow;

- Investment activity - annual change in FDI inflow;

- Efficiency of foreign trade - annual change in exports of goods and services.

The component "Social sphere" is represented by the following indicators:

- Human capital - the level of employment of the population;

- Living standards - annual change in real wages;

- Employment efficiency - labor productivity index.

The component "Corporate activity" is formed by a variable: the annual change in the foreign activity of TNCs (OECD statistics indicator - Outward activity of multinationals by industrial sector).

The component "innovation activity" is formed by the following indicators:

- innovation development - gross domestic R\&D expenditure - GERD;

- share of innovative enterprises in the total number of enterprises.

A schematic representation of the formation of the integral Country Brand Index from the relevant components (indicators and factors) is shown in Fig. 1. Proceeding from the proposed approach, the integral Country Brand Index is determined using the formula:

$$
I_{C B}=X_{1} \times a+X_{2} \times_{6}+X_{3} \times c+X_{n} \times k \times 100 \% \text {, }
$$

where $\mathrm{I}_{\mathrm{CB}}$ is the integral country brand indicator; $X_{1}, X_{2}, X_{3}, X_{n}$ - normalized values of the factors; $a, b, c$, $k$ - the contribution of each factor, estimated by the Varimax component rotation method. 
To calculate the integral Country Brand Index using Formula 1, it is necessary to determine the contribution of each factor (in this case, each indicator in the composition of $\mathrm{I}_{\mathrm{CB}}$ ) for the relevant country under study. For this purpose, we also use the method of rotation of the Varimax component rotation method.

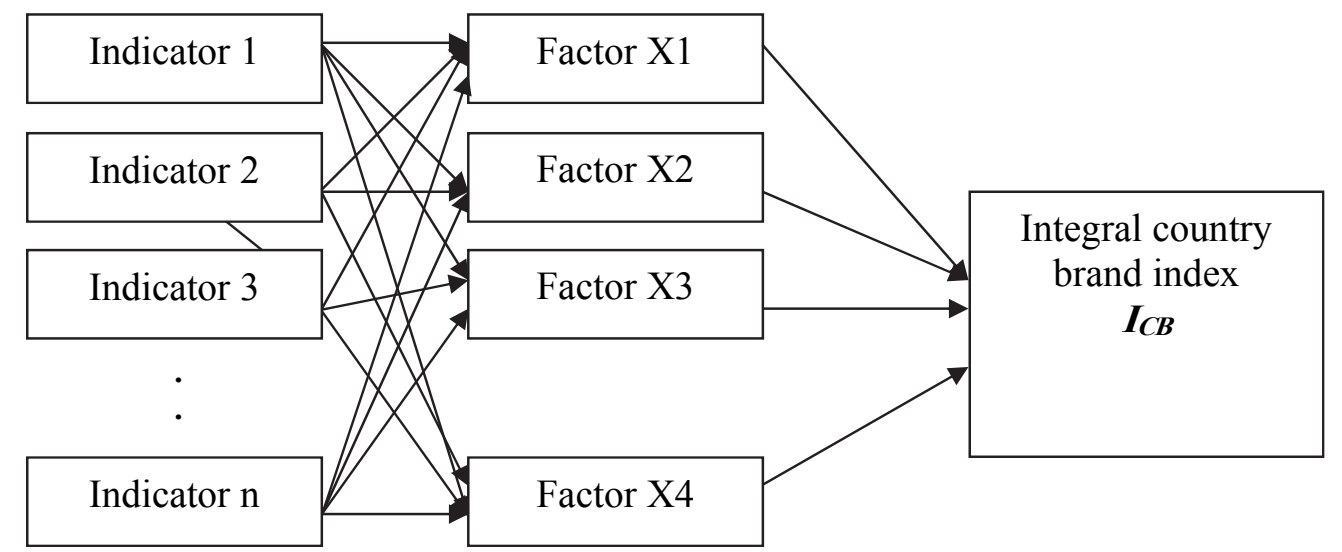

Fig. 1. Schematic representation of the influence of factors on the Country Brand

The rotation of factors was carried out to build a clear matrix (that is, one that can be interpreted) of loads, that is, factors that are marked by high loads for one and low for other characteristics. For this purpose, the Varimax factors rotation method is used more often (Kharman, 1972). The Varimax method maximizes the spread of squares of loads for each factor, which leads to an increase in the large and a decrease in the small values of factor loads. As a result, a simple structure is obtained for each factor separately. Let's note that the Varimax rotation method provides a better distribution of characteristics by factors than other methods of factors rotation (Kharman, 1972). The factors can be rotated both for input and normalized factor loads.

The results of multivariate statistical analysis of 9 input indicators based on the use of the Varimax components rotation method allowed forming the value of the contribution of each indicator to the indicator of the Country Brand Index of the countries under study.

Table 3

Results of factor analysis for determining the contribution of factors by countries

\begin{tabular}{|c|c|c|c|c|c|c|c|c|c|c|}
\hline $\begin{array}{l}\text { Country/ } \\
\text { variables }\end{array}$ & $\mathrm{X} 1$ & $\mathrm{X} 2$ & X3 & X5 & X6 & X8 & X11 & X13 & X16 & $\begin{array}{c}\text { Total contri- } \\
\text { bution of fac- } \\
\text { tors }\end{array}$ \\
\hline USA & 0.16234 & 0.15744 & 0.05254 & 0.04764 & 0.03293 & 0.05313 & 0.14274 & 0.06803 & 0.13784 & 0.85463 \\
\hline Germany & 0.15461 & 0.09011 & 0.15773 & 0.04891 & 0.01932 & 0.02341 & 0.07321 & 0.2467 & 0.13311 & 0.94711 \\
\hline Japan & 0.04045 & 0.12955 & 0.01865 & 0.02775 & 0.10315 & 0.18405 & 0.02650 & 0.13459 & 0.04675 & 0.71145 \\
\hline Austria & 0.14061 & 0.10412 & 0.16089 & 0.07319 & 0.09352 & 0.04117 & 0.15039 & 0.07013 & 0.14233 & 0.97635 \\
\hline France & 0.11854 & 0.12120 & 0.12386 & 0.10652 & 0.00174 & 0.01832 & 0.12449 & 0.03715 & 0.12980 & 0.78162 \\
\hline China & 0.09674 & 0.15028 & 0.18382 & 0.00736 & 0.12089 & 0.01443 & 0.13797 & 0.12151 & 0.12505 & 0.95804 \\
\hline Spain & 0.10164 & 0.10068 & 0.09972 & 0.09875 & 0.09779 & 0.09683 & 0.09587 & 0.09491 & 0.09395 & 0.88013 \\
\hline Russia & 0.09298 & 0.09202 & 0.15106 & 0.09010 & 0.11914 & 0.12817 & 0.08721 & 0.12625 & 0.00853 & $\mathbf{0 . 8 9 5 4 7}$ \\
\hline Poland & 0.11243 & 0.06702 & 0.17161 & 0.13620 & 0.05078 & 0.14537 & 0.13996 & 0.03455 & 0.06913 & 0.92706 \\
\hline Turkey & 0.07594 & 0.17053 & 0.06512 & 0.15971 & 0.05429 & 0.14888 & 0.14347 & 0.03806 & 0.13264 & 0.98864 \\
\hline Hungary & 0.10779 & 0.10737 & 0.11696 & 0.10655 & 0.10614 & 0.00572 & 0.10531 & 0.10490 & 0.10449 & 0.86523 \\
\hline Romania & 0.08407 & 0.18166 & 0.17925 & 0.07684 & 0.07442 & 0.07201 & 0.06960 & 0.16719 & 0.06477 & 0.96982 \\
\hline Brazil & 0.07903 & 0.07328 & 0.06754 & 0.06179 & 0.15605 & 0.05030 & 0.14455 & 0.03881 & 0.13306 & 0.80441 \\
\hline Ukraine & 0.12437 & 0.19421 & 0.23608 & 0.05472 & 0.02341 & 0.03354 & 0.0000 & 0.18003 & 0.05126 & 0.89762 \\
\hline Greece & 0.18534 & 0.10875 & 0.05001 & 0.02788 & 0.1004 & 0.05961 & 0.08114 & 0.20365 & 0.13053 & 0.94731 \\
\hline Moldova & 0.14894 & 0.05319 & 0.05745 & 0.06170 & 0.12595 & 0.07021 & 0.03462 & 0.17872 & 0.18297 & 0.91375 \\
\hline
\end{tabular}

The determined shares of the overall variance for each country show the contributions of influential factors that can be analyzed for the formation of branding strategies for the countries. According to the results of the study, it can be said that in the USA the determined factors form the resulting indicator of 
the country brand by $85 \%$; the most influential factors are GDP, foreign direct investment, TNC activities and innovative activity of enterprises. In Germany, gross domestic R\&D expenditure (GERD), the real GDP change, the dynamics of exports and the innovative activities of enterprises make a significant contribution to the country brand. In Japan, these indicators are labor productivity, gross domestic R\&D expenditure (GERD), direct foreign investment and wages. The total contribution of the determined factors to the Japanese $\mathrm{I}_{\mathrm{CB}}$ is $0.71 \%$. In China, the most influential indicators for the country brand are FDI, exports, gross domestic R\&D expenditure (GERD), foreign activities of TNCs and the share of innovative enterprises.

For the formation of the strategy of the country brand of Ukraine one should take into account the largest contributions of the factors forming it (the total contribution is $90 \%$ ), in particular, economic growth, investment and foreign trade activity, as well as the volume of innovative activity expenditures, as the improvement of dynamics according to these indicators will further increase the Country Brand Index.

Having formed the series of normalized values of the determined indicators for each country, it is possible to calculate their integral Country Brand Index (the results of calculations are given as of 2017) using Formula 1; the results are provided in Table 4.

Table 4

Calculated Country Brand Index (as of 2017)

\begin{tabular}{cccc}
\hline Country & Calculated $\mathbf{I}_{\mathbf{C B}}, \boldsymbol{\%}$ & Country & Calculated $\mathbf{I}_{\mathbf{C B}}, \mathbf{\%}$ \\
\hline China & 81.1 & Poland & 41.4 \\
USA & 80.5 & Greece & 38.5 \\
Germany & 76.4 & Russia & 35.68 \\
Austria & 72.4 & Turkey & 32.13 \\
France & 69.4 & Brazil & 31.4 \\
Japan & 69.06 & Moldova & 30.6 \\
Spain & 61.3 & Romania & 30.1 \\
\hline Hungary & 50.08 & Ukraine & 22.3 \\
\hline
\end{tabular}

The analysis of Table 4 shows that China (81.1), the USA (80.5), Germany (76.4), Austria (72.4), France (69.4), Japan (69.1) and Spain (61.3) have the largest values of the Country Brand Index. Hungary (50.1), Poland (41.1), Greece (38.5), Russia (35.7), Turkey (32.1) and Brazil (31.4) have the indexes below the average (51.7). Moldova (30.6), Romania (30.1) and Ukraine (22.3) are at the end of the list.

If we analyze the lowest value of the Country Brand Index of Ukraine determined on the basis of a set of selected indicators and their contributions to the formation of $\mathrm{I}_{\mathrm{CB}}$, it can be noted that in the period from 2000 to 2017 Ukraine was characterized by unstable economic growth with periods of crises $(2009,2014-$ 2015 ) and low growth rates (an average of 5.2\%, excluding crisis years). In 2016 and 2017, Ukraine's economy grew by about $2.5 \%$ each year. The main constraints in recent years have become the following:

1) Hostilities in the East of Ukraine, and the associated economic blockade of the occupied regions of Donetsk and Luhansk regions. As a result, Ukraine's dependence on imports of energy resources, first of all coal, a change in the ratio of capacities of various types of power plants, which exceeded the permissible loads for some of them, has become increasingly significant. This event significantly influenced the economic situation of enterprises that had stable industrial relations with the region. According to various calculations, Ukraine loses about 1\% of GDP due to the economic blockade of the occupied regions of Donetsk and Luhansk regions (ICPS, 2017);

2) Negative foreign trade balance. Asymmetries in foreign trade, insufficient lobbying of national interests, difficulties in product certification require further reforms and capacity building to ensure Ukraine's sustainable growth. Economic progress in the foreign economic sphere is restrained by the inherited and unresolved problems of the "Dutch disease" of the national economy. Domestic model of foreign trade cooperation, which is cyclical in terms of stages of growth and decline, corresponds to the level of 2010- 
2011. Short phases of export growth are accompanied by prevailing rates of import consumption, thus quickly accumulating imbalances. The established commodity structure and non-expansionary foreign trade activity remain the key factors of macroeconomic and financial pressure on the national economy, and unjustified level of openness - of high dependence on the external state of the market.

3) Underdevelopment of the banking sector. In 2017, the tendency towards a reduction in the number of banks continued, which resulted in an additional burden on the Deposit Guarantee Fund, there was an increase in the number of problem loans. The access of corporations to financial resources remains limited;

4) Increasing inflationary processes. At the end of 2017, inflation was $11.2 \%$. This is due to the abolition of state regulation of food prices, increase of minimum wages and pensions without adequate economic growth of the economy, continuation of the tendencies to increase tariffs for households, which led to an increase in users of subsidies to $60 \%$, delayed NBU resolution to raise the discount rate from $12.5 \%$ to $13.5 \%$. Another reason for the accumulation of inflationary pressure is the high cost of many types of economic activity. In most spheres of the Ukrainian economy, the level of intermediate consumption exceeds the European one. The increase in cost predetermines the use of worn-out fixed assets (over 76\% in the processing industry as of the end of 2016 (Verner, 2018)) and the domination of outdated, energyand material-consuming technologies; expensive and prohibitive credit resources.

Negative tendencies of general economic growth also cause deterioration of other analyzed indicators.

Ukraine has a low level of economic productivity, along with a reduction in the number of people employed, both in industry and in the economy in general (for 2012-2017, the average reduction was 6\% and $5.6 \%$, respectively). GDP per capita in Ukraine does not correspond to a strong human, resource, industrial and technological potential. The lagging behind the EU CEE countries is somewhat smaller, but no less significant. Thus, GDP per capita in Poland (\$13.82) is 5.4 times higher than the Ukrainian indicator, Hungary $(\$ 15,533)-6$ times, Slovakia $(\$ 17,664)-6.8$ times, the Czech Republic $(20,152$ USD) - 7.8 times, respectively. Ukraine is even inferior to such countries as Belarus (2.2 times) and Russia (4.1 times). This situation affects the problem of the systemization of excessive debt burden on the economy (in 2018, the IMF projected debt level will reach $78.4 \%$ of GDP (International Monetary Fund, 2018), thus attributing Ukraine to the top 40 countries with high debt load) and the budget (planned debt maintenance costs in 2018 amounted to $13.1 \%$ of the state budget expenditures (The State Treasury of Ukraine, 2018).

The formation of a positive image of Ukraine, and thus the growth of the $\mathrm{I}_{\mathrm{CB}}$, is hampered by the structural component of foreign trade. Thus, geographically, according to the results of 2017, EU countries generated $40.5 \%$ of domestic commodity exports and $44.5 \%$ of imports. In turn, in 2017 , the CIS countries accounted for $16.0 \%$ of exports (including Russia - 9.1\%) and 23.1\% (14.5\%) of imports, respectively (Verner, 2018). The share of trade with Asian countries (to $28.8 \%$ in the export of goods, to $21.3 \%$ - in imports) somewhat increased, Africa accounts for only $9.3 \%$ of exports and $1.4 \%$ of imports. At the same time, trade with African countries makes the most positive contribution to the balance of domestic foreign trade turnover ( $\$ 3.4$ billion in 2017). The role of the American market remains at the very edge of the presence $(2.8 \%$ - for commodity exports and a bit more for imports - $7.3 \%)$. Ukraine is also characterized by a conservation of the commodity structure of exports - these trends continued in 2017 . The goods with a low degree of processing account for more than $64 \%$ of exports, among which the most significant share is occupied by agricultural raw materials (vegetable goods $-21.3 \%$ of total exports of goods; fats and oils $(10.6 \%)$, as well as metallurgy products $(23.4 \%)$ and mineral products $(9.1 \%)$. This structure of Ukrainian exports proves the non-competitiveness of domestic high value-added goods (in 2017 , the share of ready-made electrical equipment belonging to the high-tech sector was only $9.9 \%$, chemical products $-3.8 \%$ ).

Another important factor in the formation of the Country Brand Index is the inflow of foreign investment. Ukraine has low investment attractiveness. As of the beginning of 2017, the volume of accumulated foreign direct investment (FDI) per capita in Ukraine $(\$ 1,152.6)$ is many times inferior to the level of 
EU CEE countries: Romania (\$ 4,481.8), Lithuania (\$ 6,081.2), Poland $(\$ 6,141.9)$, Latvia $(\$ 8,839.4)$, Slovakia (\$ 9,551.2), Hungary $(\$ 9,600.5)$, Czech Republic $(\$ 14,453.1)$ and Estonia $(\$ 17,675.3)$ (UNCTADstat, n./d.).

After a significant decrease in the volume of FDI in Ukraine in 2014, the period 2015-2016 was marked by the restoration of volumes of foreign investment resources in the national economy. So, in 2016, the inflow of FDI reached \$ 4.4 billion, which is 1.8 times more than in 2014 (about \$ 2.5 billion). In 2017, there was a decrease in interest of foreign investors in the economy of Ukraine. In this period, almost \$ 1.9 billion of direct investments (equity) was attracted, which is 2.4 times less than in 2016. Most foreign investments were attracted by foreign banks under recapitalization programs, which is due to the compliance with the NBU regulations. In general, the non-resident share capital in financial and insurance activities in 2017 amounted to $\$ 647.5$ million (\$2,825.3 million in 2016). In January-June 2018, these earnings amounted to $\$ 1.26$ billion.

Although foreign investors have a significant interest, investment flows do not match the potential and strategic objectives of Ukraine. The process of formation and realization of the national investment potential preserves system defects, which manifests itself in the following tendencies:

- FDI does not cause any tangible and fundamental structural and technological changes in the Ukrainian economy. Traditionally, foreign investors are oriented mainly towards highly profitable, fast-payback segments of the Ukrainian economy not related to foreign trade - financial and insurance activities, as well as the market of services with a low level of knowledge intensity (trade and real estate operations). Consequently, in the present form, the inflow of foreign capital largely consolidates the low-and lowmiddletech structure of Ukrainian industry, not focusing on the creation of industries for strategic inclusion in global value-added chains. So, if we analyze the structure of FDI according to the technological level of industry according to the classification of Eurostat (2014), in 2017 extractive industry and quarry development provided $23.5 \%$ of the total FDI growth in industry, low-tech branches of the processing industry - $33.2 \%$, medium-low-tech branches - $12.1 \%$, electric power, water and gas supply sector $22.1 \%$.

In addition, foreign investors in Ukraine are oriented primarily to sectors that do not require long-term investment and the development of new technologies. FDI also do not play a significant role in the processes of capital formation in Ukraine. Thus, in 2016, the share of foreign investors' funds in the total structure of capital investment financing amounted to $2.7 \%$, in 2017 this figure dropped to $1.4 \%(0.2 \%$ in January-June 2018);

- Preservation of low investment volumes, which are directed not to the purchase of existing companies or expansion of their activities, but to the creation of new enterprises (greenfield investments). According to UNCTAD (2017) experts, slow reforms, as well as problems in legislation and taxation system are the main factors underlying low investment volumes in the country;

- Maintaining the structure of capital inflows, which is dominated by the inflow of offshore and Russian capital. A characteristic feature of FDI in the Ukrainian economy is a significant volume of capitals controlled by foreign companies which are resident in Ukraine (Ukrainian capitals were previously withdrawn from the country, usually to off-shores (round-tripping FDI)) along with capitals directly owned by foreign residents. The analysis of the investor countries in the Ukrainian economy shows a small share of FDI from developed countries and a share of the temp of the offshore countries. As of July 1, 2018, Cyprus remained the largest investor in Ukraine (28.2\% of the total FDI). In 2017, the largest volumes of non-resident share capital came from Cyprus (\$ 506 million) and Russia (\$ 395.9 million). In 2018 (January-June), Russia and Cyprus retained their leadership in FDI inflows (\$ 436 million and \$ 219 million, respectively).

As the calculations showed, the innovative activity also contributes to the formation of the Country Brand Index of Ukraine. 
The level of innovation in the development of the country's economy determines its place and positions in the world commodity markets. This is confirmed by the well-known model of foreign trade, where the first level is represented by raw materials and agricultural commodities, the second - by products of manufacturing industry, the third - by high-tech and innovative products. However, as domestic scholars point out, modern innovation processes in Ukraine should be characterized as an innovative pause, since in the period of active innovation rulemaking and the establishment of an innovative development model innovation activity has not undergone progressive trends due to the lack of a motivational mechanism.

The weak response of the industrial sector of Ukraine to the new global trends in manufacturing show that not all Ukrainian industrial enterprises use even automation technologies - the key technology of the previous generation, while the technologies of Industry 4.0 provide for a significantly higher level of interaction of digital systems on the basis of processing of large data arrays. Examples of implementation of 4.0 systems in Ukraine are still isolated (in particular, we can cite the example of ArcelorMittal Kryvyi Rih, one of the leaders in the implementation of technologies of Industry 4.0, which actively implements the ISA 88-95 standards, the new technologies 4.0, thus improving work with contractors on this basis, etc.).

The innovative potential of the Ukrainian industry, the ability to respond quickly to changes in market conditions and technological developments is significantly limited by the low level of interaction culture in the "production-marketing-sales-service" chain, the lack of systems for the collection of information from consumers at the enterprises and quality competitive intelligence with subsequent changes to the processes of production and sale of products, as well as the low level of financial resources for development of domestic industrial enterprises. In addition, the lack of unified standards in the area of the development and integration of management systems and the determined criteria for assessing the quality of services hinders the establishment of effective cooperation between enterprises and Ukrainian IT companies, which have to give preference to work with foreign firms in the set legal field and a more favorable business climate.

In general, the IT industry in Ukraine remains inadequately structured - the domestic IT market combines different niches and segments that are difficult to divide into distinct categories. In addition, the share of IT hardware manufacturing remains small, with the main components being produced for obsolete equipment of previous generations. A significant segment of the industry belongs to the company, whose headquarters and markets are abroad, and all production is in Ukraine. The reason is that Ukraine, being surrounded by more developed sectoral markets, than its own one, offers a less skilled but cheaper workforce. Consequently, despite the significant potential, the Ukrainian IT industry is still predominantly servicing, secondary in nature, as the main source of its revenues is relatively cheap outsourcing projects for export, the adaptation of foreign software, and the provision of IT services - that is, products with low value added.

In the structure of Ukraine's GDP, the share of enterprises of the $4^{\text {th }}$ (aircraft, motor vehicles, ships, etc.) and $5^{\text {th }}$ (mobile communications, microelectronics and computer science) tenor of technology is small. Low R\&D expenditures, especially in the Ukrainian industry, do not comply with the innovation policy. Therefore, a lack of funds is traditionally considered the reason for the low level of enterprise innovation. At the same time, Ukrainian enterprises spent over $z 3$ billion for innovation activity, of which about $64 \%$ was used for technological innovations. Ukraine has to overcome a significant lag behind the level of innovation activity of enterprises, this indicator fell again (14.3\% of all enterprises) in 2017 compared to $2016(16.6 \%)$, with an average EU figure, not to mention the countries that are innovative leaders (Germany - 59\%), about 44\%).

Entrepreneurs consider a high level of risk, a significant cost of innovation, lack of own funds and government financial support, lack of information about new technologies, markets, etc. among the factors inhibiting innovation. The success of innovative industrial enterprise in the market is largely due to its ability to fulfil the tasks at a high-level, timely and skillfully in a competitive environment. In addition, an innovative product must meet the requirements of potential customers. This is how the quality of the innovation sphere as a complex system factor manifests itself, which reflects the ability to effectively 
generate, implement and distribute innovations. Its main components are the organization of innovation activities, personnel qualifications and vocational training, technical equipment, the level of contractual and executive discipline, resources of the industrial enterprise.

According to the scientists, a significant factor that also restraints the innovative activity of enterprises is the lack of solvent demand for innovative products. First of all, this is due to the slow pace of formation of the relevant market of innovative products in Ukraine, the inability of most domestic enterprises to act as equal partners at the world level, since the Western innovative product has advantages for consumers. Thus, the successful implementation of innovation activities of enterprises involves combining the efforts of the state, business, scientific organizations and enterprises, the transition to the support of competitive industrial facilities, the reduction of traditional resource-intensive industries and the growth of the role of knowledge-intensive and innovative ones.

Thus, the proposed method allows determining the integral Country Brand Index $\left(\mathrm{I}_{\mathrm{CB}}\right)$ based on socioeconomic indicators and their contribution, which makes it possible to determine the positions of countries in the world based on a comparison of $\mathrm{I}_{\mathrm{CB}}$ with the index of global competitiveness, as well as quantitatively describe the contributions of key factors forming $\mathrm{I}_{\mathrm{CB}}$ in order to formulate appropriate strategies depending on the country's position in the world. To this end, it is proposed to use the spatial set of $\mathrm{I}_{\mathrm{CB}}$ in combination with strategic analysis and planning models. As a national branding analysis tool, the Shell/DPM model is suggested for use. The Shell/DPM model was developed by the BritishDutch chemical company Shell and was called the Direct Policy Matrix (Efremov, 1997; Hichens \& Robinson, 1978; Thompson \& Strickland, 2007). The Shell/DPM matrix is a two-factor $3 \times 3$ matrix, which is based on qualitative and quantitative indicators for evaluating the resulting parameter. The advantage of the Shell/DPM matrix is the application of quantitative indicators and multi-parameter strategic analysis. The Shell/DPM model is a Cartesian coordinate system where the abscissa and ordinate axes represent respectively the strengths of the business entity (competitive position) and the attractiveness of the industry. In other words, the estimated values of the business entity's competitiveness (or its ability to use the opportunities that are available in this business environment) are reflected on the abscissa; the axis of ordinates, respectively, is a cumulative indicator of the evaluation of trends in the development of the economic sector.

To determine the country's position in the world, we propose to use the Global Competitiveness Index as the country's competitiveness (Schwab, 2017), and the calculated Country Brand Index - as development prospects.

The Global Competitiveness Index includes more than 100 indicators that measure the competitiveness of the state through quantitative and qualitative assessments. The World Economic Forum makes up the Global Competitiveness Index of 12 elements (sub-indexes), which are factor drivers of the economy, drivers of economic efficiency and innovation drivers (Schwab, 2017). The Global Competitiveness Index includes the data of the survey of managers of international companies that assess the business climate in the country, the factors of business activity. The share of qualitative assessments accounts for about $70 \%$ of the indicators that form the index. Official statistics and data base of international studies account for $30 \%$.

According to the results of 2017 (a total of 137 countries are listed in the ranking), Switzerland (5.86), the United States (5.85), Singapore (5.71), the Netherlands (5.66), Germany (5.65) held the leading positions in terms of GCI. Ukraine ranked $81^{\text {st }}$ with a value of 4.11 , which is close to Bhutan (4.10), Brazil (4.14), Tajikistan (4.14) and Serbia (4.14). At the same time, Ukraine's position in the last year has strengthened compared to $85^{\text {th }}$ place (out of 138 countries). Table 5 presents the rankings and values of GCI and the CBI of the countries under study. 
Table 5

The value of the Global Competitiveness Index (GCI) and the Calculated Country Brand Index (2017) (Schwab (2017) and calculated by the author)

\begin{tabular}{cccc}
\hline Country & GCI & $\begin{array}{c}\text { Ranking } \\
\text { (out of 137 countries) }\end{array}$ & Calculated ICB \\
\hline USA & 5.85 & 3 & 80.5 \\
Germany & 5.65 & 5 & 76.4 \\
Japan & 5.49 & 9 & 69.06 \\
\hline Austria & 5.25 & 18 & 72.4 \\
France & 5.18 & 22 & 69.4 \\
China & 5.00 & 28 & 81.1 \\
Spain & 4.70 & 34 & 61.3 \\
Russia & 4.64 & 38 & 35.68 \\
\hline Poland & 4.39 & 39 & 41.4 \\
Turkey & 4.42 & 53 & 32.13 \\
\hline Hungary & 4.33 & 60 & 50.08 \\
Romania & 4.28 & 68 & 30.1 \\
Brazil & 4.14 & 80 & 31.4 \\
\hline Ukraine & 4.11 & 81 & 22.3 \\
\hline Greece & 4.02 & 87 & 38.5 \\
\hline
\end{tabular}

As we see from Table 5, there is some discrepancy in the ranking for GCI and $\mathrm{I}_{\mathrm{CB}}$. The calculated China's $\mathrm{I}_{\mathrm{CB}}$ proved to be the largest and puts the country in the first place in terms of the country brand, followed by the United States, Germany and Austria. In this connection, the task is to compare these indices on a single plane in order to determine the strategies of positioning countries in the world.

The Shell/DPM matrix is proposed for development of the country brand management models by the indicators: competitiveness - Global Competitiveness Index and the country brand development - calculated Country Brand Index - through the example of the countries under study. The positioning of countries by the country brand is represented in a matrix of nine quadrants whose boundaries are calculated by means of average values (Fig. 2).

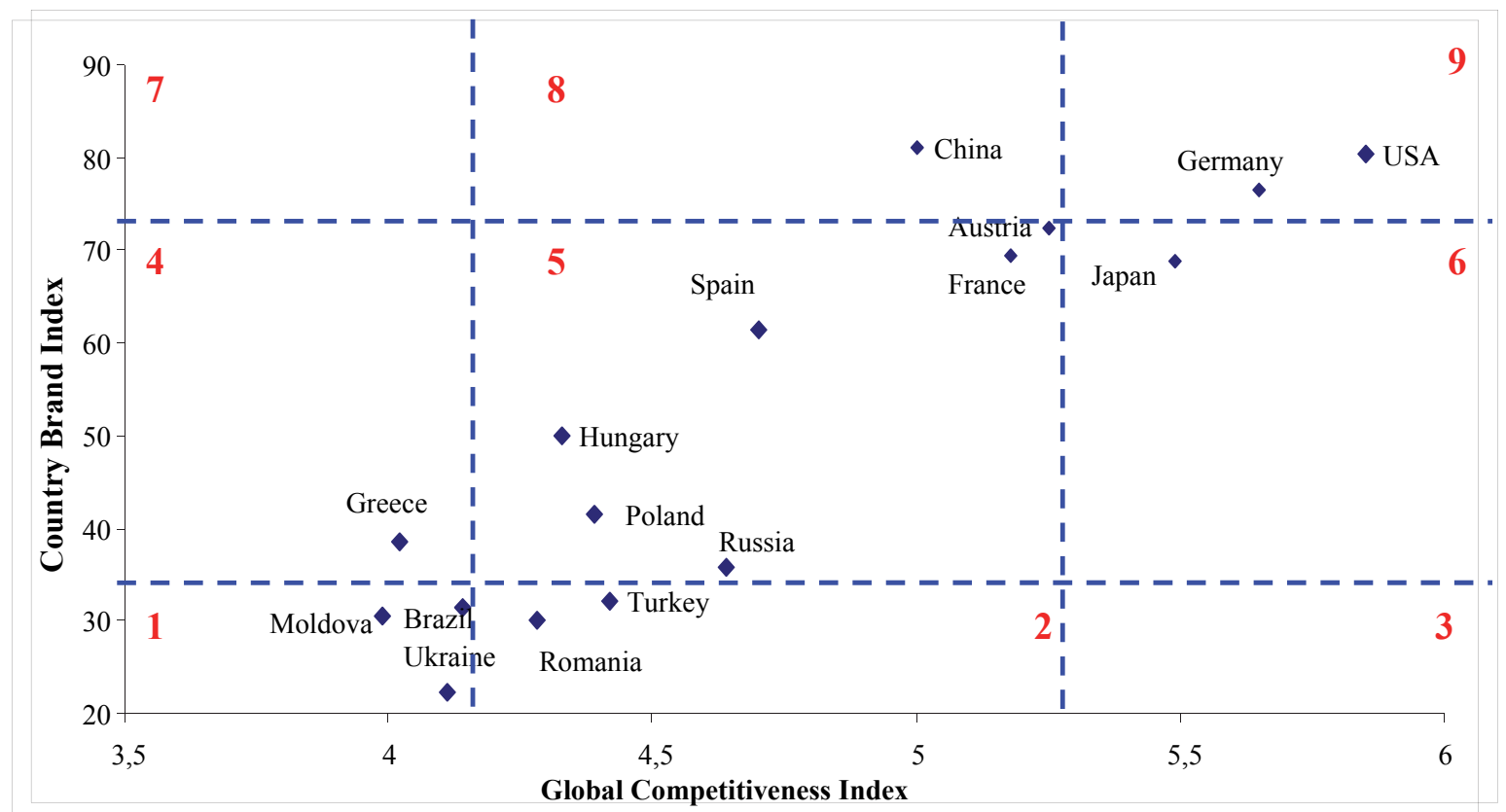

Fig. 2. Positioning of the countries by Country Brand according to the Shell/DPM (built by the author based on Schwab (2017) and own calculations) 
The first quadrant in the matrix is represented by three countries - Brazil, Moldova and Ukraine. These states have weak positions both in terms of GCI and the calculated Country Brand Index. According to the established economic indicators, countries have low levels of economic development (at least unstable GDP growth rates, foreign investment and foreign trade (exports), in addition, the weak level of human capital development and the extremely low level of innovation in the economy). In this aspect, states use technology borrowing strategies as well as product and process simulations. These countries do not implement the internationalization of production (there are almost no own TNCs operating in other countries). This leads to a low level of competitiveness in the global market.

This quadrant of the matrix can be called the "Development Strategy", because after analyzing the positions of these countries, it can be noted that the options of their transition to the $2^{\text {nd }}$ sector (through increasing the competitiveness index), to the $4^{\text {th }}$ sector (provided the growth of the country brand index) and, in the best case, to the $5^{\text {th }}$ sector (provided that both indicators are improved) are possible. The existing obstacles in the growth of overall competitiveness are, however, considered to be an expedient shift in the indicators forming the Country Brand Index. For Brazil, for example, it is the growth of real wages, foreign activities of TNCs and the share of innovative enterprises; for Moldova, the focus should be on overall economic growth (GDP), growth of wages, expenditures for innovations and the growth of the share of innovative enterprises.

Countries in the $2^{\text {nd }}$ sector are Turkey and Romania. The competitiveness of their economies occupies middle positions, but the prospects for developing their country brands are rated as weak. The strengths and opportunities of the brand are not effectively used. This sector is entitled the "Country Brand Strengthening Strategy". For these countries, the transition to $5^{\text {th }}$ sector is the most likely - through increasing the Country Brand Index due to improved indicators: for Turkey - foreign direct investment, employment rate, labor productivity, foreign activities of TNCs, share of innovative enterprises; for Romania - the volume of foreign investment and R\&D government spending.

The $4^{\text {th }}$ sector is represented by one country - Greece. Its position is characterized by a weak competitiveness level and a moderate level of prospects of the country brand. This quadrant can be described as the "Strategy for Increasing Competitiveness". In this case, the main strategy for the countries of this quadrant should be the transition to the $5^{\text {th }}$ quadrant, which means strengthening the competitive position in the world market and trying to improve the indicators by 12 elements of the Global Competitiveness Index.

Six countries - Austria, France, Spain, Hungary, Poland and Russia - got to the $5^{\text {th }}$ quadrant, which is the middle of the presented matrix. Moreover, their placement in the plane of the ordinates is completely different - Poland and Russia are in the lower part of the quadrant, Hungary and Spain - in the middle, and Austria and France are quite close to the next promising sectors. This means that the development strategies of these countries should be different. In general, the quadrant is characterized by moderate values of the competitiveness index and average values of the Country Brand Index. A strategy for this sector can be described as the "Strategy for Increasing Competitiveness with Promising Development of a Country Brand". In this aspect, recommendations for Hungary, Poland and the Russian Federation - strengthening the country brand positions, in particular efforts should be aimed at improving the following indicators: for Hungary - GDP, FDI, exports, employment, wages, TNCs' foreign activities, public spending on innovation and share of innovative enterprises; for Poland - GDP, exports, employment, labor productivity and TNCs' foreign activities; for the RF - exports, wages, labor productivity and total expenditures for innovations. The improvement of Spain's $I_{\mathrm{CB}}$ will bring its position closer to the $8^{\text {th }}$ sector due to the growth of the dynamics of GDP and FDI. Otherwise, strengthening of global competitiveness positions will cause its shift towards the $6^{\text {th }}$ quadrant. The possible (unlikely) simultaneous growth of both indices will lead to the country's shift to the upper part of the quadrant - to France and Austria. As for the latter, it should be noted that the high values of the Austrian $\mathrm{I}_{\mathrm{CB}}$ allow it to occupy a place in the $8^{\text {th }}$ quadrant in the near future, or even to get into $9^{\text {th }}$ (provided simultaneous improvement of the dynamics of both indices. For France, which is also close to the $6^{\text {th }}$ and $8^{\text {th }}$ sectors, it is possible to 
recommend either to strengthen the $\mathrm{I}_{\mathrm{CB}}$ positions through increasing the rates of foreign investment, exports and TNCs' foreign activities, which will lead the country to reaching up the $8^{\text {th }}$ quadrant, or to join the 10 leaders in terms of the Global Competitiveness Index, which will shift the country to the $6^{\text {th }}$ sector.

The $6^{\text {th }}$ sector is represented by Japan - a country with a high level of global competitiveness and an average level of the Country Brand Index. This quadrant can be described as the "Leader Succession Strategy", which means improving the Country Brand Index while keeping the country's GCI positions, with the growth of the following indicators: FDI, wages, labor productivity and gross R\&D expenditures.

Sector 8, "Strategy for Radical Advancing and Leadership Expectation", is characterized by high I $\mathrm{CB}$ and moderate GCI, only China from the countries under study got into it. Improving positions in terms of the Global Competitiveness Index (getting into top-10) will allow China to take its place in the $9^{\text {th }}$ quadrant of the matrix.

Sector 9 is represented by the leading countries, both in terms of GCI, and calculated $\mathrm{I}_{\mathrm{CB}}$ - the United States and Germany. It can be described as the "Strategy of Leadership, Maintenance of Sustainable Positions". These are countries with a powerful innovative industrial complex, a high level of development of human potential and labor productivity, the expansion of their own TNCs, which form powerful brands in the world. It provides a high level of economic development and leadership in competitiveness in the global environment.

As Figure 1 shows, none of the studied countries got into the $3^{\text {rd }}$ quadrant (high competitiveness with low prospect of the country brand) and the $7^{\text {th }}$ quadrant (low competitiveness with a high prospect of the country brand). This can be explained by the close relationship between the indices of global competitiveness and the country brand, based on the fact that the country cannot take high places in the world in terms of competitiveness without creating a strong country brand and vice versa.

Thus, based on the foregoing, we present the general scheme of formation of country brand strategies in the context of global competitiveness on the basis of the proposed approach, which allows analyzing the current and prospective state of the country and its place in the world, tracking the shifts in quadrants in dynamics. Figure 3 shows the characteristics of the built Shell/DPM matrix with the corresponding possible cross-sectional shifts of positions (shown with arrows).

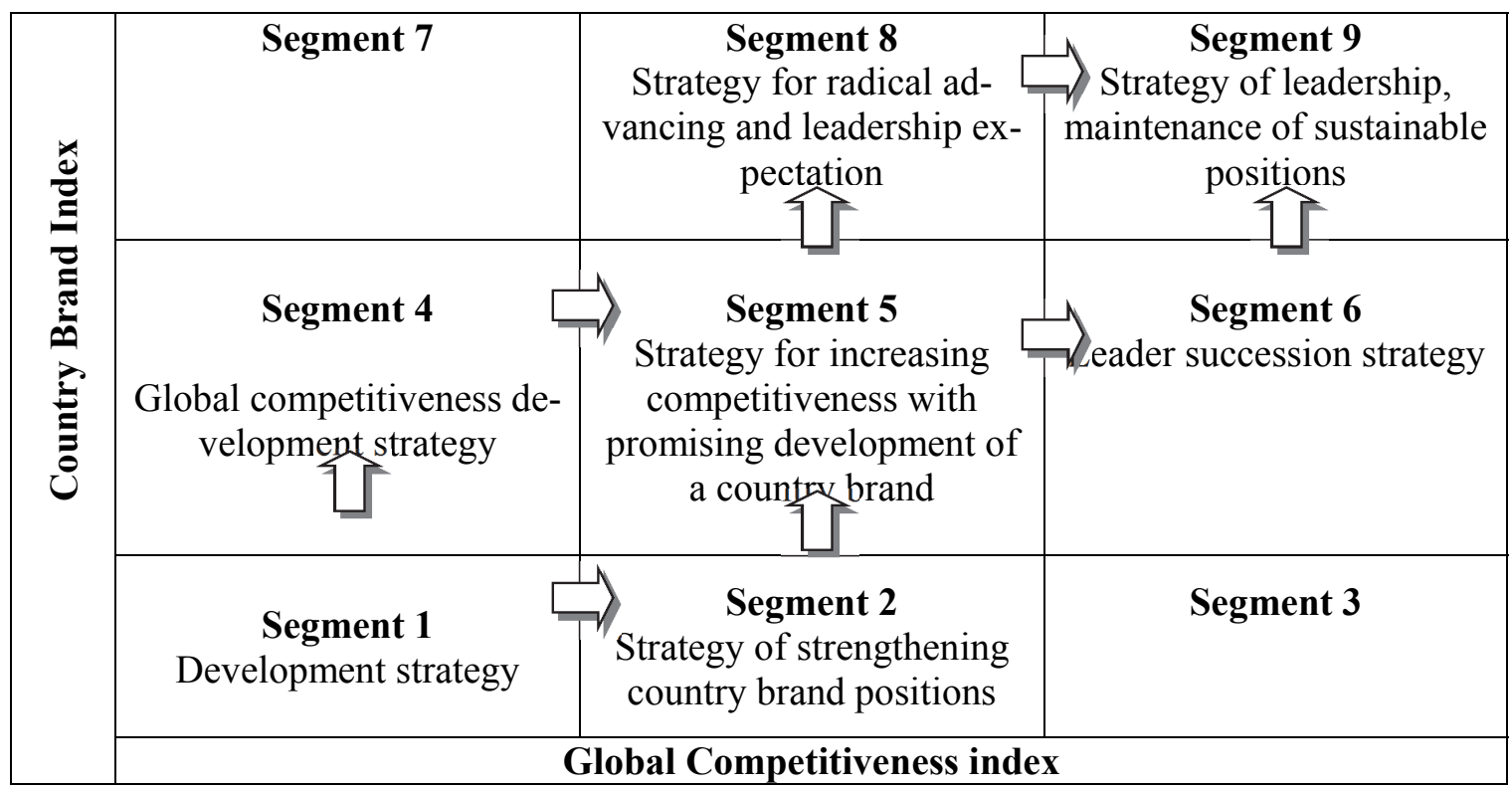

Fig. 3. National brand strategies for the Shell/DPM model

The presented methodological approach can be further applied to the study of more countries (it has no limitations), to study the indicators in dynamics and to compare the positions of the countries in the 
matrix according to the previous year, to group the countries according to the corresponding strategy of development of the country brand and competitiveness, and also on the basis of the analysis to make decisions on the strategic directions of the country brand development based on the determined factors and their assessed contributions to the formation of the Country Brand Index.

\section{Conclusions}

Based on the analysis of the leading global ranking agencies: Brand Finance, Anholt-GfK Nation Brand Index, Bloom Consulting, and Future Brand Company, key indicator variables that influence the efficiency of the brand strategy and the country competitiveness in the world are systematized. On the basis of the economic-mathematical method of the main components by the Kaiser criterion, significant factors shaping these indicators are selected.

As a result of multivariate statistical analysis, 16 input indicators based on the use of the Varimax rotation method were divided into 4 groups of integral factors. The first one is interpreted as macroeconomic (the share of the contribution of the factor to the integral Country Brand Index is $31.5 \%$ ), the second factor the social component - forms the resulting indicator by $27.7 \%$ ), the contribution of the third factor, determined as the corporate one, is $10.8 \%$, the fourth factor represents the innovative component of the Country Brand Index and forms it by $21.2 \%$. According to the given model, the total contribution of the selected factors in the formation of the Country Brand Index was 91\%.

In the component of the integral Country Brand Index, "Macroeconomics", the following indicators had the greatest burden on the resulting indicator: economic growth - GDP (real growth); investment activity - annual change in direct foreign investment inflow; the effectiveness of foreign trade - annual change in exports of goods and services. The component of the "social sphere" is represented by the following indicators: human capital (employment rate of the population); living standards of the population (annual change in real wages); employment efficiency (Labor Productivity Index). The component "corporate activity" forms an indicator of the annual change in the foreign activities of TNCs. The component "innovation activity" is formed by the following indicators: gross domestic R\&D expenditures and the share of innovative enterprises in the total number of enterprises.

The determined shares of the total variance (using the Varimax method) for each country show the contributions of influential factors that can be analyzed for the formation of branding strategies for the countries. Thus, in order to formulate the country brand strategy of Ukraine, one should take into account the largest contributions of the factors forming it (the total contribution is 90\%), in particular economic growth, investment and foreign trade activity, as well as the volume of expenditures for innovative activity, as the improvement of dynamics of these indicators in the future will lead to an increase in the Country Brand Index.

The analysis of the calculated Country Brand Index of Ukraine allowed identifying the main reasons for its low level: unstable economic growth with periods of crises $(2009,2014-2015)$ and low growth rates due to the increase in Ukraine's dependence on import of energy resources, asymmetries in foreign trade, underdevelopment of the banking sector, intensification of inflationary processes against the background of the domination of obsolete, energy- and material-consuming technologies; expensive and prohibitive credit resources.

In order to formulate appropriate strategies, depending on the position of the country in the world, a tool for analyzing national branding - the Shell/DPM model was used; its benefits are the use of quantitative indicators and multi-parameter strategic analysis. The Global Competitiveness Index was used as a country's competitiveness, and the calculated Country Brand Index - as a prospect of development.

The matrix of prospects for the development of a country brand allows analyzing the current and prospective state of the country and its place in the world, tracking the shifts in quadrants in dynamics. As a result, 9 quadrants are distinguished that describe the prospects of the country brand development, based on the positions of global competitiveness: 1 - development strategy (Brazil, Moldova and Ukraine); 2 
- strategy for strengthening brand positions (Turkey and Romania); 4 - global competitiveness development strategy (Greece), 5 - the strategy for increasing competitiveness with prospects for the country brand development (Austria, France, Spain, Hungary, Poland and Russia), 6 - the leader succession strategy (Japan), 8 - the strategy for radical advancing, leadership expectation (China), 9 - strategy of leadership, maintenance of sustainable positions (USA, Germany).

\section{References}

Afifi, A., \& Azen, S. (1982). Statistical Analysis. Computer-Aided Approach. Moscow: Mir.

Anholt, S. (2007). Competitive Identity: The New Brand Management for Nations, Cities and Regions. Basingstoke, UK: Palgrave Macmillan.

Aronczyk, M. (2013). Branding the Nation - The Global Business of National Identity. New York: Oxford University Press.

Dinnie, K. (2008). Nation Branding - Concepts, Issues, Practice, Butterworth Heinemann. Oxford: United Kingdom.

Efremov, V.S. (1997). Classic Strategic Analysis and Planning Models: Shell/DPM. Management in Russia and foreign, 3, 34-39.

Eurostat. (2014). Eurostat indicators of High-tech industry and knowledge - intensive services. Annex 3 - High-tech aggregation by NACE Rev. 2. Available at http://ec.europa.eu/eurostat/cache/metadata/Annexes/htec_esms_an3.pdf

Fan, Y. (2006). Nation Branding: What is Being Branded? Journal of Vacation Marketing, 12(1), 5-14.

Fetscherin, M. (2010). The Determinants and Measurement of a Country Brand: the Country Brand Strength Index. International Marketing Review, 27(4), 466-479.

Hichens, R. E., \& Robinson, S. J. (1978). The Directional Policy Matrix: Tool for Strategic Planning. Wade Long Range Planning, 11, 8-15.

International Center for Policy Studies (ICPS). (2017). Economic Development of Ukraine 2017: Achievements, Failures, Prospects. Available at http://icps.com.ua/ekonomichnyy-rozvytokukrayiny-2017-dosyahnennya-nevdachi-perspektyvy/

International Monetary Fund. (2018). World Economic Outlook Database. Available at http://www.imf.org/external/pubs/ft/weo/2018/01/weodata/weoselgr.aspx

Kaiser, H. F. (1960). The application of electronic computers to factor analysis. Educational and Psychological Measurement, 20, 141-151. http://dx.doi.org/10.1177/001316446002000116

Keller, K. L. (2012). Strategic Brand Management: Building, Measuring, and Managing Brand Equity, 4th edition. New Jersey: Pearson.

Kharman, H. H. (1972). Modern Factor Analysis. Moscow: Statistics.

Kotler, P., \& Gertner, D. (2002). Country as brand, product, and beyond: A place marketing and brand management perspective. Journal of Brand Management, 9(4/5), 249-261.

Nahorniak, T. (2010). The Image, Brand and Reputation of the Territory in Political Science and Practice. Tribuna, 5-6, 43-44.

OESD. (n./d.). Official OESD Statistics. Available at https://stats.oecd.org/

Papadopoulos, N., \& Heslop, L. A. (2002). Country Equity and Country Branding: Problems and Prospects. Journal of Brand Management, 9(4/5), 294-314.

Polishko, H. H. (2013). International Ratings of Country Brands and Assessment of the Brand of Ukraine. Crimean Economic Bulletin, 2(6), 109-112.

Schwab, K. (Ed.). (2017). The Global Competitiveness Report 2017-2018. Geneva: World Economic Forum.

Shevchenko, O. V. (2003). PR Technologies in International Relations (European Experience and Perspectives of Ukraine): monograph. Kyiv: Free Press Center.

Shtelmashenko, A. D. (2013). The Brand of the State: the Essence and Peculiarities of Formation. Scientific Bulletin of the Academy of Municipal Management. Series: Management, 2, 348-356. 
Starostina, A., Kravchenko, V., \& Lychova, H. (2011). The International Image of the Country: Practical Aspects of the Analysis. Marketing in Ukraine, 3, 49-58.

Temporal, P. (2014). Branding for the Public Sector: Creating, Building and Managing Brands People Will Value. Available at http://site.ebrary.com.ezproxy.jamk.fi:2048/lib/jypoly/detail.action?do$\mathrm{cID}=10990950$

The State Treasury of Ukraine. (2018). Report on Fulfilment of the Budget of Ukraine for January-April 2018. Available at https://www.treasury.gov.ua/ua/file-storage/misyachniy-zvit-pro-vikonannyaderzhavnogo-byudzhetu-ukraini-za-sichen-kviten-2018-roku?page=2

Thompson, A. A., \& Strickland, A. J. (2007). Strategic Management: Concepts and Situations for Analysis. Moscow: Williams.

UNCTAD. (2017). World Investment Report 2017: Investment and the Digital Economy. Geneva: United Nations.

UNCTADstat. (n./d.). Statistical Indicators. Available at http://unctadstat.unctad.org/wds/ReportFolders/reportFolders. aspx?sCS_ChosenLang=en

Verner, I. Ye. (Ed.). (2018). Statistical Yearbook of Ukraine for 2017. Kyiv: State Statistics Service of Ukraine.

Zavhorodnia, T. V. (2010). Global Brands in Modern Marketing Technologies. Abstract thesis. Kyiv.

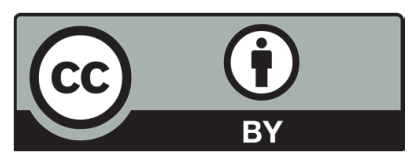

(C) 2019 by the authors; licensee Growing Science, Canada. This is an open access article distributed under the terms and conditions of the Creative Commons Attribution (CCBY) license (http://creativecommons.org/licenses/by/4.0/). 